\title{
Learning Media Development of Analyzing Poetry-Building Element Using Sparkol Videoscribe
}

\author{
Anggi Surya Septianti ${ }^{*}$, Mulyadi Eko Purnomo ${ }^{2}$, Sri Indrawat ${ }^{3}$ \\ ${ }^{123}$ Master of Language Education Program, Sriwijaya University, Palembang \\ e-mail: angginonot@gmail.com 1 , mulyadiekopurnomo@yahoo.com ${ }^{2}, \underline{\text { sriindrawati207@gmail.com }}^{3}$
}

\begin{abstract}
This study aims to develop learning media to analyze the building blocks of poetry by using sparkol videoscribe in $10^{\text {th }}$ grade students. This research is a development research (R\&D). This research method is used to produce certain products, and test the effectiveness of these products. Data collection techniques used were interviews, questionnaires, and learning outcomes tests. The data analysis technique was carried out by analyzing the questionnaire which was seen from the results of the high and low percentage of the needs desired by students and the next teacher. Based on the results of product trials, it shows an increase in learning outcomes of 36.76, with a pretest mean of 41.96 while postest was 78.92. Based on these findings it can be concluded that the development of learning media to analyze the building blocks of poetry using sparkol videoscribe has an effect on the learning outcomes of $10^{\text {th }}$ grade students.
\end{abstract}

Keywords: Learning Media, Poetry, Sparkol VideoScribe

\section{Introduction}

As science and technology develop, teachers are required to be able to design their own learning by utilizing various types of appropriate IT-based learning media so that the learning process takes place effectively and efficiently (Hartanto, 2016; Nisa, 2018; Widyaningsih et al., 2020). Learning can be said to be effective if it is able to provide new experiences to students to achieve predetermined learning goals (Prasetya et al., 2020; Ramansyah, 2014). Students can experience firsthand learning that uses learning media as a tool, so learning is produced from the most concrete to the most abstract levels, so that students will get more and more learning experiences (Amin, 2019; Rahmi et al., 2019). However, if students only become listeners and make the teacher the center of learning, not students who experience the learning directly, then there is little experience gained by students from the learning process. Therefore, teachers must be able to manage students, learning activities, materials, resources, and learning media.

Learning media plays an important role in the learning process, because learning media is a tool or message channel that can represent the teacher in conveying information in a more thorough, clear, and interesting manner and makes it easier for students to understand the learning material presented. Learning media are anything that can be used to convey or transmit messages from a source in a planned manner, so that a conducive learning environment occurs so that the recipient can carry out the learning process efficiently and effectively (Hartini et al., 2017; Oktasari et al., 2019). In addition, it also states that learning media is a means or tool that functions as an intermediary for conveying learning messages, so that it can stimulate the thoughts, feelings, attention, and willingness of students in order to encourage the learning process in students (Amin, 2019; Ramansyah, 2014).

Learning media are generally used with the aim of making the learning process more effective and efficient in accordance with the desired learning objectives. In order for the learning media to be more attractive, supporting applications must be added so that the learning process becomes more interesting, innovative and interactive. Learning media is important to use, because in using learning media it will arouse student interest and

\footnotetext{
${ }^{*}$ Corresponding author.
}

Received 24 August 2020; Accepted 04 September 2020; Available online 01 December 2020 (c) 2020 JPI. All Rights Reserved 
motivation, reduce verbalism, as a channel of information, encourage students, and increase knowledge retention in learning so that it can maximize the achievement of learning goals (Amin, 2019). So that in general the benefits of learning media are to facilitate interaction between teachers and students so that learning activities are more effective and efficient. The use of instructional media really needs to be used in all subjects, one of which is Indonesian.

However, from the results of an interview with one of the Indonesian language subject teachers on November 28, 2018, during the learning process in the classroom the teacher still used conventional learning, with the teaching materials used, namely textbooks and worksheets. Meanwhile, the use of learning media for teachers has not been maximally used, usually only using power point presentations that are displayed on an LCD projector, but the power points used are only ordinary slides that do not display audio and video. So that this problem is what causes the lack of interest of students during the learning process, especially in learning material to analyze the elements of building poetry.

The problems that occur cause the level of understanding of students to the material being taught is not optimal and tends to be low. The low level of students' understanding of the material taught conventionally without the media that becomes the teacher's aid during the learning process becomes one of the problems in learning, namely analyzing the elements of building poetry. Students still have difficulty understanding the structure of the poetry appropriately, because the teacher only provides explanation material in the package book, the poetry that is served is in the form of writing such as poetry that is already in the textbook, and students only record the material on the blackboard only (Jaya et al., 2013; Melasarianti et al., 2019; Sutikno, 2016). Therefore students still have difficulty understanding the subject matter and tend to feel bored so that it makes students less active during the learning process. To overcome the above problems, the teacher should try to create new experiences for students during the teaching and learning process. The provision of this implementation can be done by using learning media during the learning process so that learning attracts students more interest in learning. And with the use of the media it is hoped that learning will be carried out more actively and the material explained is easy to understand so that the learning objectives to be achieved can be achieved. One of the learning media that is considered to be able to attract students' learning interest and make students more active and easier to understand each learning process is by developing media that can display videos or reading poetry, material, for example, practice questions and evaluation in one container in the form of learning media. Learning media that can support the success of the learning implementation process, one of which is the sparkol videoscribe learning media.

The sparkol videoscribe media is an animated video learning medium consisting of a series of images arranged into a complete video (Amin, 2019; Pamungkas et al., 2018; Pratiwi et al., 2019). Sparkol videoscribe as a relevant learning medium in the world of education is able to increase students' interest in learning. Sparkol videoscribe can increase the enthusiasm of students in participating in learning because this learning media is able to provide a fun and more effective learning experience. In addition, also with the use of sparkol videoscribe learning media, students get positive learning experiences so that they can provoke ideas and inspire in participating in learning (Amin, 2019; Pamungkas et al., 2018; Widayanti \& Aisyah, 2019). Video sparkol media has unique characteristics, namely being able to present learning content by combining images, sound, and attractive designs so that students are able to enjoy the learning process (Basuki \& Sholeh, 2018; Pamungkas et al., 2018; Setiyowati \& Panggayuh, 2019). Learning media with sparkol videoscribe can also be used in poetry learning, by using sparkol videoscribe, poetry learning becomes more interesting because it can display learning material supported by video, audio, and animated images.

Several studies conducted regarding the development of sparkol videoscribe were carried out by (Munawar \& Suryadi, 2019) which stated that based on the feasibility level of the validation results of material experts, media experts, and learning experts, respectively, the results were $88.55 \%, 94.65 \%$, and $93.75 \%$. and the results of the students' assessment of $86.5 \%$. Thus, this media is suitable to be used as a medium of learning material on the Islamic Kingdom in Java with the sub-material of the Kingdom of Demak. Then the research 
conducted by (Pamungkas et al., 2018) stated that the sparkol videoscribe media received an assessment by subject content experts reaching good categories, learning media experts achieved good categories and small group validations reached good categories. Then the research conducted by (Nurrohmah et al., 2018) stated that the quality of the product developed was very feasible with a score of 3.37 based on material expert judgment and 3.56 by media experts in the very feasible category. Student responses to learning media assisted with sparkol video on assignment material (linear program) obtained a score of 3.55 with very interesting criteria.

There are differences between this research and existing research, namely: 1) the research conducted by (Amin, 2019) did not conduct tests on experts because this research activity is a community service in the form of ICT media development workshops that can increase the understanding of elementary school teachers in Tulusbesar Village, Malang Regency in creating and using learning media with the sparkol videoscribe application, 2) research conducted by (Munawar \& Suryadi, 2019) is the development of videoscribe for Indonesian history subjects with the material of the Kingdom of Demak, 3) research conducted by (Pamungkas et al., 2018) namely the development of sparkol videoscribe in the mathematics history course.

This study aims to develop learning media to analyze the poetry-building elements using sparkol videoscribes on $10^{\text {th }}$ students of SMA Bina Warga 2 Palembang, which are in accordance with the analysis of the needs of students and teachers, to produce a valid, practical prototype, and effective against learning outcomes for students.

\section{Method}

This study is a research and development. This research method is used to produce certain products, and test the effectiveness of these products. This study refers to the development model of Allesi and Trollip. The research was conducted at SMA Bina Warga 2 Palembang, the subject of research was $10^{\text {th }}$ grade students, and it was conducted in 20182019 academic year in the even semester.

Development using the Allesi and Trollip model which is oriented towards learning media products which is carried out in three stages, namely the planning, design and development stages. This study developed learning media to analyze the building blocks of poetry using sparkol video scribes which were tested for validity, practicality, and effectiveness. Allesi and Trollip suggest that there are 3 (three) criteria for measuring the quality of learning products, namely alpha test, beta test, and product test.

Data collection techniques used were interviews, questionnaires, and learning outcomes tests. There are two types of data produced, namely qualitative data and quantitative data. Qualitative data were obtained from interviews and data from the analysis of the needs of students and teachers. Quantitative data is obtained from the results of alpha testing, beta testing, and product trials.

The data analysis technique was carried out by analyzing the questionnaire which was seen from the results of the high and low percentage of needs desired by students and teachers, then a conclusion was drawn. At the alpha test stage, the questionnaire data analysis was carried out which had been assessed by the validator, seen from the results of the mean score of the validity level which was very high, high, quite high, low, very low. Furthermore, the beta test stage was also carried out by analyzing the questionnaire data to determine the practicality of the media developed from the results of the average score obtained, including in the very practical, practical, quite practical, impractical, very impractical category. At the product trial stage, data analysis of student learning outcomes was carried out by comparing the results of the pretest and posttest values which referred to the difference in the $\mathrm{n}$-gain value.

\section{Result and Discussion}

This research is a development research that uses the Allesi and Trollip development model. The Allesi and Trollip development model consists of 3 stages, namely the planning stage, the design stage, and the development stage. 


\section{Planning Stage \\ At the planning stage there are eight steps. The steps are as follows.}

The first step of the needs analysis by conducting interviews and questionnaires to class X students and Indonesian language subject teachers at SMA Bina Warga 2 Palembang. The results of the interviews and questionnaires were that students were less skilled at analyzing the building blocks of poetry because of limited learning time, lack of understanding of the structure of poetry, furthermore students revealed that in the learning process the learning media were not applied, the teaching materials used were limited to textbooks. and worksheets. Apart from that, from the results of the interview the teacher only became a facilitator in the learning process. Students and teachers need teaching materials that can help facilitate the learning process in the classroom, and can help students to be able to study anywhere and anytime without depending on the presence of the teacher. Therefore, students and teachers expect innovation and a new learning atmosphere in order to increase the understanding and abilities of students.

The second step is to identify the scope of limitations in the development of instructional media. The basic competency chosen is 3.17 to analyze the building blocks of poetry. The material includes the meaning of poetry, the building blocks of poetry which consist of physical and mental structures. The physical structure consists of typography, figurative language, diction, pengimajian, and concrete words, while the inner structure consists of taste, tone, message, and theme.

The third step was to analyze the characteristics of students. The analysis phase of the characteristics of students who will be the target of students in $10^{\text {th }}$ grade of science class 2 , each child has diverse abilities, those are high, medium and low abilities. Based on observations of students of $10^{\text {th }}$ grade of Science 2 class, they are already accustomed to using technology in daily life such as cell phones and computers/laptops, so that researchers can apply learning media by using sparkol videosribe on $10^{\text {th }}$ grade students of SMA Bina Warga 2 Palembang.

The fourth step was analyzing facilities. From the observations made by researchers at SMA Bina Warga 2 Palembang, they already have adequate facilities and infrastructure with infocus in each class and have been installed permanently and also have a computer lab. Their computers have as many as 30 units in good condition, and are equipped with wifi making it easier for researchers when conducting research with the help of the internet.

The fifth step was analyzing the curriculum. The researcher chooses the material analyzing the poetry-building elements where this material which is contained in the even semester syllabus of the 2013 curriculum with subject matter 8 understands poetry, which was the focus of this study 3.17 basic competencies analyze the poetry-building elements. The selection of basic competencies is based on the results of direct interviews with Bahasa Indonesia study teacher Mr Andika, where students still have difficulty in understanding the material analyzing the elements of poetry building, causing the time needed in class is very short. So that the impact on student learning outcomes obtained was quite low.

The sixth step was to make a planning document. Sparkol videoscribe learning media development planning document by making work concepts of what is done in a certain time and detailing the research development schedule conducted by the researcher.

The seventh step was to discuss the initial idea. The initial idea of the researchers discussed with the supervisor and programmer, discussed about the form of media/features to be developed and matched them with indicators of achievement of the material.

The eighth step gets the client's approval. The last stage of the production planning was to get direct approval from the client, namely approval from the school where the product trial will be conducted. The researcher received approval from the school principal and Bahasa Indonesia teacher at SMA Bina Warga 2 Palembang and also received approval from the supervisor in the form of a research proposal.

\section{Design Step}

In the designing step, researchers conducted activities to develop the initial concepts of learning media using sparkol videoscribe. There were several steps of research design that 
will be developed. The initial steps of developing ideas. Ideas developed regarding the presentation of content, appearance, images, animations, videos, songs, and programming. This stage includes an initial description of the program to be developed. Next do the analysis of concepts and tasks. Task analysis was used to determine the task to be carried out in media development, while for the concept it was used to organize concepts that can be from ideas that have been developed. The next step determines the initial program. In the development of learning media that will be developed using Software or the sparkol videoscribe application and supported by the camtasia application so that the sparkol videoscribe learning media becomes more interactive, so that the videos used are easier to operate.

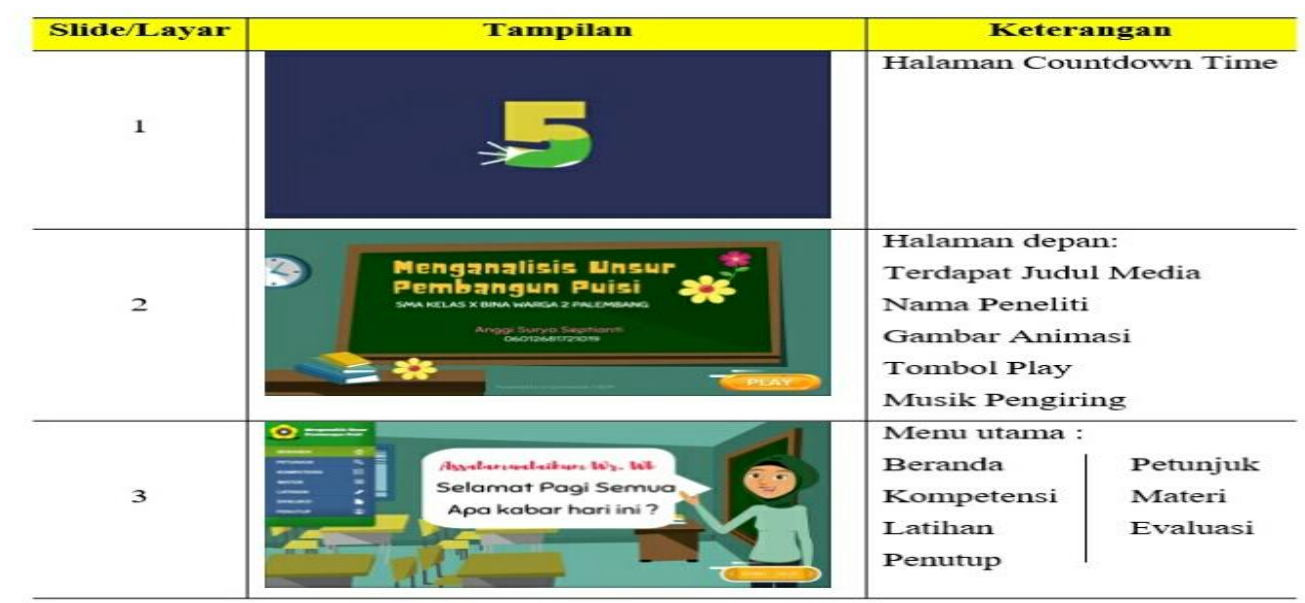

Figure 1. Prototype of Sparkol Videoscribe Learning Media

\section{Development Step}

At this step the activities carried out were: (1) preparpreparing audio and video files used in learning media such as audio or sound that were made to accompany live recorded text and accompaniment music, while videos made using software sparkol videoscribe; (2) making instructions for use are made to make it easier for students to know the button symbols that are in the learning media; (3) preparing supporting material to be included in the learning media; (4) conducting alpha test on a team of experts consisting of lesson material, language and media experts; (5) conducting a beta test toward 9 students to measure the practicality of the developed learning media; (6) testing the product on 25 students of $10^{\text {th }}$ grade.

The final form of the product being developed was a learning media analyzing the poetry-building elements using sparkol videoscribes on $10^{\text {th }}$ grade students of SMA Bina Warga 2 Palembang in the form of learning videos.

\section{Alpha Test Data Analysis (Validation Results)}

The alpha test stage of the learning media analyzes the building blocks of poetry using sparkol videoscribe conducted from April to May. Aspects that are validated are material / content, language, and media.

The results of the feasibility of the material/content gave a value of 104 with an average of 4.00 included in valid category and when viewed from the validity level obtained a score of 0.75 included in high category. Learning media analyzing the poetry-building elements using sparkol videoscribe at SMA Bina Warga 2 Palembang deserves to be tried in this study. The assessment language expert evaluation of learning media using sparkol videoscribe was 53 with an average score of 4.41 including very valid category and when viewed from the validity level obtained a score of 0.85 with a very high category. Learning media analyzing the poetrybuilding elements using sparkol videoscribe declared valid in terms of language and deserve to be tested. The results of the media validation in the alpha test, the media validator gave a value of 95 with an average of 4.52 with a very valid category and in terms of the level of validity obtained a score of 0.88 with a very high category. So the learning media analyzing 
the poetry-building elements using sparkol videoscribe at SMA Bina Warga 2 Palembang deserves to be tested in research.

Table 1. Alpha Test Results for Sparkol Videoscribe Learning Media

\begin{tabular}{cccccc}
\hline Aspect & Validator & Total Score & Average & V & Category \\
\hline Material & DS & 104 & 4,00 & 0,75 & Valid/ High \\
language & SM & 53 & 4,41 & 0,85 & Very Valid / Very high \\
Media & PPS & 95 & 4,52 & 0,88 & Very Valid / Very high \\
\hline
\end{tabular}

\section{Beta Test (Practicality Test)}

The beta test was carried out on 9 randomly selected students, namely students with low, medium, and high abilities with the aim of knowing the products that have been developed can be used easily by students in the learning process. the instrument used was a practicality questionnaire.

Based on the results of the practicality questionnaire on the beta test, there are 6 aspects that are assessed. The content feasibility aspect got a mean of 4.22 very practical category, the presentation feasibility aspect was 4.22 with the very practical category, the graphic aspect got an average of 4.08 with the practical category, the interactive aspect got a mean 4.27 with the very practical category, the sound aspect obtained a mean of 4.29 with the very practical category and the language aspect got a mean of 4.33 with the very practical category. The overall results of the learning media assessment obtained a value of 4.23 which is included in the very practical category.

\section{Product Trial}

At the product trial step, effectiveness test was conducted on the students. The effectiveness test of learning media was carried out in two ways, those were the test before using learning media analyzing poetry-building elements using sparkol videoscribe (pretest) and tests after using learning media analyzing poetry-building elements using sparkol videoscribe (posttest). The subject of research in the effectiveness test of this learning media was $10^{\text {th }}$ grade students of SMA Bina Warga 2 Palembang.

Researchers conducted a pretest to see the understanding and ability of students towards learning to analyze the poetry-building elements. After obtaining the results from the pretest, the researcher analyzes the results of the students' pretest according to the rubric of assessment. The next step, a product trial is conducted by giving learners the developed learning media.

Provision of learning media and testing in the same class in the pretest trial is on $10^{\text {th }}$ grade students of Bina Warga 2 Palembang. Students use learning media to analyze the poetry-building elements using sparkol videoscribe when teaching and learning in class. When the learning process takes place learners learn to use learning media independently with teacher supervision. When learning activities take place the things done by students are understanding poetry material that is already in the learning media such as, understanding poetry, birth structure and inner structure, examples of analyzing poetry, exercises about understanding and analyzing poetry questions.

After students learn and do all the exercises contained in the learning media, posttest is done to see the effectiveness of the learning media used by students. After obtaining the results from the posttest, the researcher analyzes the results of the posttest learners according to the rubric of assessment. Pretest and posttest were used to find out the comparison and increase in the ability to analyze the poetry building elements of students before and after using learning media to analyze poetry-building elements using sparkol videoscribe.

\section{Pre-test results}

The field trial was conducted by researchers at Palembang's High School Bina Warga 2 on Friday, March 29, 2019 in $10^{\text {th }}$ grade of Science 2 for two hours of learning ( $2 \times 45$ minutes) at $9.45-11.15$ at the initial stage of the study which was to give a pre-test question (pretest). 
At the time all students in $10^{\text {th }}$ grade of Science class 2 as 25 students. Data of students' pretest results at the first meeting can be seen in the following table

Table 2. Recapitulation result of Pretest

\begin{tabular}{cccc}
\hline Score Interval & Number of students & Percentage & Category \\
\hline $90-100$ & & & very good \\
$80-89$ & & & good \\
$60-79$ & 5 & $20 \%$ & Relatively good \\
$50-59$ & 20 & $80 \%$ & Low \\
$0-49$ & 25 & $100 \%$ & very Low \\
Jumlah & & 41,96 & Poor \\
\hline
\end{tabular}

Based on the results of the pretest in the table above, it shows that no students get score of 90-100. Whereas for the 50-59 scores there were 5 students and 0-49 scores as many as 20 students, so it can be concluded that the pretest could be attended by all students of $10^{\text {th }}$ grade students of Science class 2 totaling 25 students were declared not to have reached the KKM (Minimum Competency achievement) with an average score of 41,96 which was included in the poor category.

\section{Post-test results}

Posttest was given after the students used learning media to analyze the poetrybuilding elements using sparkol videoscribe after the learning process whose purpose was to measure the learning outcomes of students after carrying out the learning process by using learning media to analyze poetry-building elements using sparkol videosribe. The implementation of the posttest was followed by students of $10^{\text {th }}$ grade of science class 2 as 25 people who took place on Saturday, for 2 hours (2x45 minutes) at 8:00 - 9.30 the posttest results data can be seen in the following table:

Table 3. Postest Recapitulation Results

\begin{tabular}{|c|c|c|c|}
\hline Score Interval & Number of students & Percentage & Category \\
\hline $90-100$ & 3 & $12 \%$ & very good \\
\hline $80-89$ & 9 & $36 \%$ & good \\
\hline $60-79$ & 13 & $52 \%$ & Relatively good \\
\hline $50-59$ & & & Low \\
\hline $0-49$ & & & Very Low \\
\hline Jumlah & 25 & $100 \%$ & \\
\hline \multicolumn{2}{|c|}{ Average } & 78,92 & good \\
\hline
\end{tabular}

Based on the results of the posttest in the table above, it can be said that there was an increase in learning outcomes to analyze the building blocks of poetry after using sparkol videoscribe media in the learning process. seen from the acquisition of 90-100 scores as many as 3 students, $80-89$ scores as many as 9 students, and $60-79$ scores as many as 13 students. Meanwhile, none of the students got a score of $0-50$. It was concluded that the results of the posttest carried out by students increased by an average of 78.92 with a good category.

\section{Comparative Analysis of Pretest and Posttest Results}

After knowing the results of the pretest and posttest shows that there are quite diverse differences. The following comparison of the results of the pretest and posttest material analyzes the poetry-building elements and N-Gain. The pretest and posttest results showed an increase in value of 36,76 and an $\mathrm{N}$-gain value of 0.64 , which means the effectiveness of 
the learning media was in medium category. Therefore it can be concluded that the learning media analyze the poetry-building elements by using sparkol videoscribe in $10^{\text {th }}$ grade of science class 2 of SMA Bina Warga 2 Palembang has an effect on the effectiveness of student learning outcomes.

\section{Discussion}

The results obtained after a needs analysis are that learning Indonesian has not used the media optimally in the learning process. At the time of the learning process, only a few uses of media such as textbooks, worksheets, and powerpoints are still very simple to use in learning, so that the enthusiasm and involvement of students in the learning process is still not optimal.

Starting from some of the problems above, learning media was developed using sparkol videoscribe which is expected as a forum to overcome these problems. Learning media is made as attractive as possible by combining sound files, animation, and video so that the learning process, especially Indonesian subjects, is expected to be more interesting, fun, motivating, arousing students' interest in learning, increasing student learning activeness and learning effectiveness of students, especially in subject matter. Indonesian, and the existence of learning media can help teachers facilitate the learning process. Sparkol videoscribe media is a good media to use in the Indonesian language learning process because sparkol videoscribe can combine sound, animation, and video files (Maulina et al., 2019; Pamungkas et al., 2018). Sparkol videoscribe has the convenience of making an attractive learning video so that the use of animated videos can provide visual simulations that can increase student interest in learning. Sparkol Videoscribe also provides very diverse features so that it can become a learning medium that can be tailored to your needs and in addition to using the designs provided in the application, users can create animation, graphic, or image designs that suit their needs and then import them into the application (Pamungkas et al., 2018; Rahmatika \& Ratnasari, 2018). Making sparkol videoscribe is also done offline or without the internet, so that teachers do not depend on internet services (Munawar \& Suryadi, 2019) so that this will make it easier for teachers to make digital-based learning media in today's era.

Research and development of instructional media produces media that has been tested for its validity. Based on the results of the alpha test conducted by 3 experts, it shows that the learning media to analyze the building blocks of poetry using sparkol videoscribe have met the requirements both in terms of material, language, and media aspects. The average acquisition of material experts was 4.00 , the mean acquisition of linguists was 4.41 , while for media experts the average acquisition was 4.52 with a very valid category. This description shows that the learning media to analyze the building blocks of poetry using sparkol videoscribe is included in the valid category according to material experts and very valid according to linguists and media experts. So that the media can be used in learning because it is considered valid and worthy of being used as supporting media during the learning process..

Beta test was carried out on 9 students with high, low, and moderate ability categories by giving questionnaires and providing an assessment of the learning media that had been developed. This is due to knowing how the practicality of learning media when viewed from the point of view of students can be categorized as practical. From the results of the questionnaire, it was obtained a mean value of 4.23 indicating that the media developed was in the very practical category and could be carried out in the research process. This is because the media developed has met the requirements of students' needs such as, the material displayed is easy to understand, the presence of interesting poetry reading videos, equipped with analysis examples, the existence of practice questions and analysis exercises, and is equipped with an evaluation learning

To measure the results of the effectiveness of sparkol videoscrie learning media on the material to analyze the building blocks of poetry, pretest and posttest activities were carried out. From the two tests carried out, it can be seen the difference obtained and the N-gain result. The pretest was carried out before students learned using learning media, it could be 
seen the results of the students' pretest with an average score of 41.96. Posttest was carried out after students used learning media with the acquisition of a core mean of 78.92. Judging by the difference between the pretest and posttest results, the score was 36.76 with the $\mathrm{N}$ gain result of 0.64 . According to Hake (1998), if $0.7>\mathrm{N}$-gain $\geq 0.3$, it is included in the moderate category. This means that learning media analyzes the elements of poetry building by using sparkol videoscribe in $10^{\text {th }}$ grade of SMA Bina Warga Palembang has an influence on the effectiveness of student learning outcomes. This is because students really have an interest in learning and are interested in the learning process so that students do not feel bored following the learning. Interest and motivation to learn will have a positive effect on learning outcomes (Rohana \& Wahyudin, 2017). The unique characteristics possessed by Sparkol Videoscribe are able to present learning content by combining images, sounds and attractive designs so that students are able to enjoy the learning process and the results of students 'post tests are greater than the results of students' pre-tests so that sparkol videoscribe is said to have an influence on the effectiveness of learning outcomes. learners. The development of learning media using sparkol videoscribe in this study is proven to be able to increase the interest of students to pay attention to ongoing learning so that the learning process runs conducive. This is in accordance with the statement (Pamungkas et al., 2018) that sparkol videsocribe can increase the enthusiasm of students in following lessons because this learning media is able to provide a fun and more efficient learning experience.

The results of this study are also in line with research conducted by (Munawar \& Suryadi, 2019) which resulted in the eligibility of the validation results of material experts, media experts, and learning experts respectively with a percentage of $88.55 \%, 94.65 \%$, and $93.75 \%$. and the results of the students' assessment of $86.5 \%$. Thus, this media is suitable to be used as a medium of learning material on the Islamic Kingdom in Java with the sub-material of the Kingdom of Demak. Then the research conducted by (Pamungkas et al., 2018) states that the evaluation of subject content experts reaches good categories, learning media experts reach good categories and small group validations reach good categories.

The implication of this research is to be able to create a class atmosphere that is conducive, interesting and of course can increase the motivation of students in learning, the development of learning media in order to help implement the learning process is very appropriate to use. The development of sparkol video social media can be used as a reference that has a positive impact on learning.

\section{Conclusion}

Based on the research results, it can be concluded that the resulting prototype is declared valid by the team of experts at the alpha test stage and the development of learning media analyzes the elements of building poetry stated effective after testing the product on students of class $10^{\text {th }}$ with $\mathrm{N}$-gain results in the medium category. The implication of this research is to be able to create a class atmosphere that is conducive, interesting and of course can increase the motivation of students in learning, the development of learning media in order to help implement the learning process is very appropriate to use. The development of sparkol video social media can be used as a reference that has a positive impact on learning.

\section{References}

Amin, S. (2019). Peningkatan Profesionalisme Guru melalui Pelatihan Pengembangan Media Pembelajaran Sparkol Videoscribe di Kabupaten Malang. Jurnal Pengabdian Pada Masyarakat, 4(4), 563-572. https://doi.org/10.30653/002.201944.238

Basuki, U. J., \& Sholeh, M. (2018). Pengembangan Bahan Ajar Pendidikan Pancasila Berbasis Multimedia dengan Menggunakan Aplikasi Sparkol Videoscribe. Jurnal Disprotek, 9(1). https://doi.org/10.34001/jdpt.v9i1.654

Hartanto, W. (2016). Penggunaan E-Learning Sebagai Media Pembelajaran. Jurnal Pendidikan Ekonomi: Jurnal IImiah IImu Pendidikan, IImu Ekonomi Dan IImu Sosial, 10(1). https://jurnal.unej.ac.id/index.php/JPE/article/view/3438 
Hartini, S., Misbah, D., Oktovian, R. A., \& Aisyah, N. (2017). Developing learning media using online prezi into materials about optical equipments. Jurnal Pendidikan IPA Indonesia, 6(2), 313-317. https://doi.org/10.15294/jpii.v6i2.10102

Jaya, S., R, S., \& Ermanto. (2013). Peningkatan Keterampilan Menulis Puisi Melalui Media Gambar Siswa Kelas X1 SMA Negeri 2 Kota Sungai Penuh. Jurnal Bahasa, Sastra, Dan Pembelajaran, 1(2), 87-95.

Maulina, U., Hikmah, S., \& Pahamzah, J. (2019). Attractive Learning Media to Cope with Students' Speaking Skills in the Industry 4.0 Using Sparkol Videoscribe. Online Submission, 2(5), 132-140. https://eric.ed.gov/?id=ED598724

Melasarianti, L., Krisnawati, V., \& Martha, N. U. (2019). Peningkatan Keterampilan Menulis Puisi Media Gambar Pahlawan Nusantara. JINoP (Jurnal Inovasi Pembelajaran), 5(1), 56. https://doi.org/10.22219/jinop.v5i1.7785

Munawar, A., \& Suryadi, A. (2019). Pengembangan Media Pembelajaran Sejarah Indonesia Berbasis Videoscribe Materi Kerajaan Islam Di Jawa Kelas X Tahun Ajaran 2018/2019 Di SMA Negeri 3 Salatiga. Indonesian Journal of History Education, 7(2), 174-184. https://doi.org/10.15294/ijhe.v7i2.36436

Nisa, C. L. (2018). Pengaruh Pembelajaran E-Learning Terhadap Hasil Belajar Mata Kuliah Statistics Mahasiswa Tadris Bahasa Inggris Fakultas Tarbiyah lain Walisongo. Jurnal Phenomenon, 2(1), 7-27. https://doi.org/10.21580/phen.2012.2.1.416

Nurrohmah, F., Putra, F. G., \& Farida, F. (2018). Development of Sparkol Video Scribe Assisted Learning Media. Formatif: Jurnal IImiah Pendidikan MIPA, 8(3), 233-250. https://doi.org/10.30998/formatif.v8i3.2613

Oktasari, D., Hariadi, M. H., \& Syari, E. L. (2019). 3D Page-Flipped Worksheet on ImpulseMomentum to Develop Students' Scientific Communication Skills. Jurnal Pendidikan IPA Indonesia, 8(2), 211-219. https://doi.org/10.15294/jpii.v8i2.15737

Pamungkas, A. S., Ihsanudin, I., Novaliyosi, N., \& Yandari, I. A. V. (2018). Video Pembelajaran Berbasis Sparkol Videoscribe: Inovasi Pada Perkuliahan Sejarah Matematika. Prima: Jurnal Pendidikan Matematika, 2(2), 127. https://doi.org/10.31000/prima.v2i2.705

Prasetya, S. P., Segara, N. B., \& Imron, A. (2020). Effectiveness Of Outdoor Learning Optimization Program In Learning Social Studies. JPI (Jurnal Pendidikan Indonesia), 9(2), 314. https://doi.org/10.23887/jpi-undiksha.v9i2.19160

Pratiwi, E. D., Latifah, S., \& Mustari, M. (2019). Pengembangan Media Pembelajaran Fisika Menggunakan Sparkol Videoscribe. Indonesian Journal of Science and Mathematics Education, 2(3), 303-309. https://doi.org/10.24042/ijsme.v2i3.4355

Rahmatika, D. F., \& Ratnasari, N. (2018). Media Pembelajaran Matematika Bilingual Berbasis Sparkol Videoscribe. Desimal: Jurnal Matematika, 1(3), 385-393. https://doi.org/10.24042/djm.v1i3.3061

Rahmi, M. S. M., Budiman, M. A., \& Widyaningrum, A. (2019). Pengembangan Media Pembelajaran Interaktif Macromedia Flash 8 Pada Pembelajaran Tematik Tema Pengalamanku. International Journal of Elementary Education, 3(2), 178-185. https://doi.org/10.23887/ijee.v3i2.18524

Ramansyah, W. (2014). Pengembangan Multimedia Pembelajaran Interaktif Berbasis Adobe Flash CS3 pada Kelas 1 SDN Bancaran 3 Bangkalan. Edutic-Scientific Journal of Informatics Education, 1(1), 28-37. https://doi.org/10.21107/edutic.v1i1.396

Rohana, R., \& Wahyudin, D. (2017). Project based learning untuk meningkatkan berpikir kreatif siswa SD pada materi makanan dan kesehatan. Jurnal Penelitian Pendidikan, 16(3), 235-243. https://ejournal.upi.edu/index.php/JER/article/view/4817

Setiyowati, P., \& Panggayuh, V. (2019). Pengaruh model pembelajaran discovery learning 
menggunakan video scribe sparkol terhadap hasil belajar SMK Perwari Tulungagung kelas X tahun ajaran 2017/2018. JOEICT (Jurnal of Education and Information Communication Technology), 3(1), 12-21. https://doi.org/10.29100/joeict.v3i1.694

Sutikno, S. (2016). Pengembangan Model Sinektik Pada Pembelajaran Menulis Puisi Berkonteks Multikultural Dalam Pembentukan Karakter Siswa SMA. Indonesian Language Education and Literature, 1(2), 221. https://doi.org/10.24235/ileal.v1i2.225

Widayanti, E., \& Aisyah, S. (2019). Penerapan Model Pembelajaran Treffinger Berbantukan Software Sparkol Videoscribe Untuk Meningkatkan Pemahaman Matematis Siswa. Kalamatika: Jurnal Pendidikan Matematika, 4(2), 117-128. https://doi.org/10.22236/KALAMATIKA.vol4no2.2019pp117-128

Widyaningsih, S. W., Yusuf, I., Prasetyo, Z. K., \& Istiyono, E. (2020). Online interactive multimedia oriented to HOTS through e-learning on physics material about electrical circuit. JPI (Jurnal Pendidikan Indonesia), 9(1), 1. https://doi.org/10.23887/jpiundiksha.v9i1.17667 